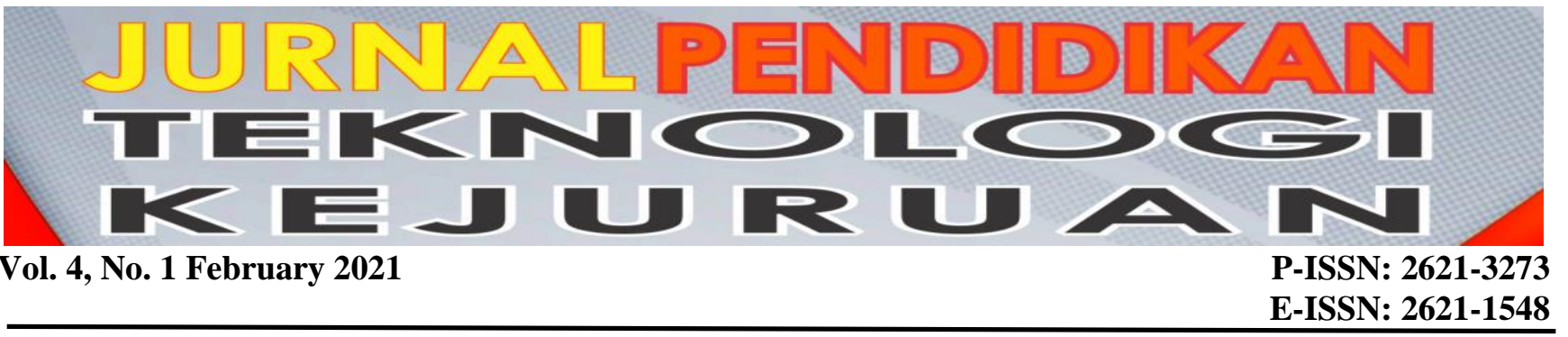

\title{
Attendance Management Based on MVC and Laravel in The Municipal Government of Pekanbaru
}

\author{
Eka Sabna $^{1 *}$, Dedy Yasriady², M.Giatman ${ }^{3}$ \\ ${ }^{12}$ Technical Information, STMIK Hang Tuah Pekanbaru \\ ${ }^{3}$ Universitas Negeri Padang \\ ${ }^{*}$ Corresponding author, e-mail: es3jelita@yahoo.com ${ }^{1}$
}

\begin{abstract}
Currently, the management of employee attendance in the City Government is still done manually, where the leadership does not have any media that can be used to monitor attendance, causing problems including recapitulation and slow employee attendance reporting. The calculation of the percentage (\%) of the employee performance allowance (Tukin) is not carried out proportionally according to the attendance discipline. The impact of the current system is undisciplined employee attendance. Attendance management system which aims to manage employee attendance data. Attendance data obtained every morning and evening is stored on a server at the Pekanbaru City Information and Communication Office. This data is then processed to determine the whereabouts of an employee and become a reference for determining the percentage $(\%)$ of the performance allowance that will be received. In addition, this attendance management can be used by Regional Leaders and Heads of Services / Institutions to monitor employee attendance quickly and quickly. The research method used for data collection is to use interviews and literature. While the method in software development uses the method of The Rapid Application Development (RAD). Attendance Management is built on the basis of the Laravel framework using the MVC (Model View Controller) method. The MVC programming pattern that separates logic and views makes program code cleaner, easier to trace when troubleshooting or debugging. The Blade feature of laravel makes using html / php templates simple. This application provides online information about employee attendance. Regional Leaders, Heads of Services / Institutions can monitor the condition of employee absenteeism in Pekanbaru City Government online every day. Employee attendance reports for each Department / OPD are generated automatically. The Personnel and Human Resources Development Agency can use it as a monthly attendance summary report.
\end{abstract}

Keyword: Laravel, OOP, Framework, Management, MVC

\section{INTRODUCTION}

The Attendance System is a very important part of a company, school, government agency or other organization that requires time discipline for members / employees. Time to go to work and time to go home are recorded in a storage and at the end of the month copied and calculated in the form of a summary and monthly reports. To achieve a good information system, information technology is needed which includes computer technology, communication technology and any technology that can provide added value to manage the system. (Jogiyanto, 2009). Attendance or attendance card is a document that records the attendance hours of each employee in a company which can be in the form of a regular attendance list or an attendance card filled with a time recording machine (Setiawan, 2015). The performance of ASN (state civil apparatus) employees greatly determines the quality of the progress of a city. It is very important to enforce employee discipline in order to provide maximum performance in community service. The presence of employees in a timely manner is the first step in shaping employee performance discipline, in this case it is necessary to establish a system that can monitor employee attendance accurately and as soon as possible. Currently, the Pekanbaru City Government Service and OPDs do not yet have media that can be used to monitor the presence of ASNs in the City Government and do not yet have an automatic employee attendance summary and reporting system. Based on this, government agencies are required to 
perform good, fast and efficient management of attendance data processing (Hasibuan, 2008).

To solve this problem, a web-based attendance management system is needed which aims to manage employee attendance data. Attendance data obtained every morning and evening is stored on a server at the Pekanbaru City Communication and Information Agency. This data is then processed to determine the presence of an employee and become a reference for determining the percentage $(\%)$ of the performance allowance that will be received. In addition, this attendance management can be used by regional leaders and heads of offices / agencies to monitor employee attendance quickly. Attendance Management is made as a web application, and is built based on the Laravel framework using the MVC (Model View Controller) method. The MVC programming pattern that separates logic and view causes the program code to be cleaner, easier to trace when doing troubleshoot or debugging. The Blade feature of laravel makes using html / php templates simple. Besides, Laravel adopts the concept of Object Oriented Programming (OOP) programming so that the application is scalable, can be further developed easily, and has several other advantages provided by the OOP concept.

Research Results Rika Nurikawati (2016) The attendance application using the laravel framework can facilitate management of employee attendance more effectively and quickly. Research by Gita Suci Lestari (2018) The Employee Attendance Application provides information about employee discipline based on the suitability of attendance time, the calculation of employee salaries can be obtained automatically according to the working hours of each employee. So with this employee attendance application is expected to be able to minimize the absenteeism problems that exist in the Office of Communication and Information Technology Pekanbaru City.

\section{Attendance Management System}

Attendance Management System is a set of methods used to produce efficient work activities and effective results in managing employee attendance in an organization. In general, the system to be built will be used to monitor the daily attendance of employees, make monthly recapitulation reports and calculate the amount of benefits that employees will receive.

\section{PHP Programming Language}

Understanding PHP according to Anhar (2010: 23) PHP is (PHP Hypertext Preprocessor) is a web programming language in the form of a script that can be integrated with HTML". PHP was first developed by Rasmust Lerdorf in 1995, and currently PHP was further developed by The PHP Group. PHP is a scripting language where the program code can be seen and read directly by humans. Line by line of program code is executed by a translator. In this case the PHP application is a translator to run PHP scripts.

\section{MVC method}

Model-View-Controller (MVC) is a concept introduced by Smalltalk's inventor (Trygve Reenskaug) to encapsulate data along with processing (model), isolating it from manipulation (controller) and view (view) to be represented on a user interface. . MVC follows the most common approaches of Layering. Layering is just a piece of logic that divides our code into functions in different classes. This approach is easily recognized and the most widely accepted. The main advantage of this approach is code reusability. (Abd. Rachman Dayat, Liza Angriani, 2017: 417).

\section{Laravel Framework}

According to David Naista (2016: 5) Laravel is an open source PHP-based web application framework, using the Model - View - Controller (MVC) concept. Laravel is licensed under the MIT License, using GitHub as a place to share code. Laravel is a framework used in creating web applications, using the PHP programming language. Laravel uses the MVC method and the OOP (Object Oriented Programming) concept in implementing the applications it creates.

\section{METHOD}

The system development method used is Rapid Application Development or commonly abbreviated as RAD, which is a linear sequential software application development process that emphasizes the development cycle in a short and fast time. RAD uses an iterative method (iterative) in developing a system where a system working model is constructed at the beginning of the development stage with the aim of determining user requirements. The form of the RAD method can be seen in Figure 1. 


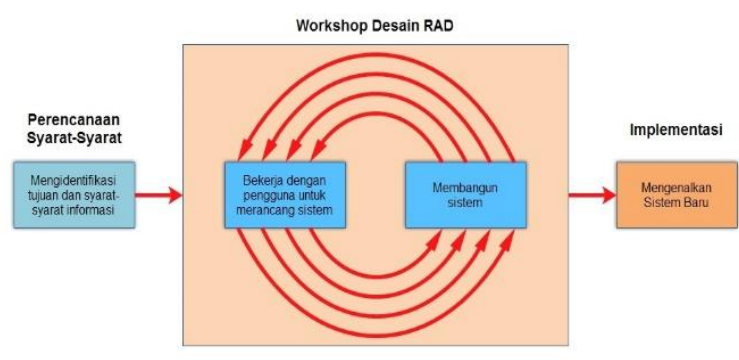

Figure 1. The Rapid Application Development (RAD) Method

\section{A. Requirement Planning}

At the planning stage of this system, meetings and discussions were held with the Head of the Pekanbaru City Communication and Information Agency (Kadis) along with the Head of the E-Government and Information Technology Organizing Division to discuss the features that need to be made. After planning the required features, a meeting was held with the Head of the Personnel and Human Resources Development Agency (BKPSDM) and the Head of Personnel to discuss policies and regulations from the Mayor that govern the amount of performance allowances for employees. Also discussed is the calculation of the minutes of delay against the percentage $(\%)$ of the discount according to the applicable representative.

\section{B. System Design}

In this process, an Attendance Management system is designed, during this process the researcher makes a system design in accordance with the agreement that was agreed in the previous stage. During this design process, Diskominfo as the organizer of the Absence Management system is actively involved to determine the suitability of the design to the agreed requirements.

\section{Implementation}

This stage is the implementation of application development carried out by the researcher, in accordance with the designs made in the previous stage.

During the development process the researcher provides a progress report on the activities that have been achieved. The Ministry of Communication and Information as a stakeholder is also actively involved in conducting running tests of the application to be made and providing comments on features that have been made according to the agreement. Tests are carried out within a certain period of time to find if there are errors and deficiencies.

\section{Problem analysis}

In conducting the analysis, it is necessary to analyze the performance, information, economy, application security, customer service efficiency which is generally known as PIECES (Performance, Information, Economic, Control, Efficiency, Services). With this analysis, several problems will be identified and finally the main problems that are targeted can be found.

a. Perfomance. Making the recapitulation more complicated and done carefully manually so that no errors occur.

b. Information . Attendance information and calculation of performance allowances take time to obtain.

c. Economic It takes the cost of procuring daily attendance forms in the form of paper and printing costs.

d. Control. It is difficult to control attendance whether the employee in question actually comes to the office, or is left absent.

e. Efficiency . The Head of Sub-Division of General Affairs must come to the attendance table every time he will see and monitor the daily attendance of employees, or ask the admin staff to get daily attendance papers.

f. Service.The process of controlling attendance must be done manually by analyzing the attendance and initials of employees one by one.

\section{System Planning}

Use Case Diagrams are used to provide an overview of the functional requirements of the application being made. This section will show the interaction between the user and the application. The following is the Use Case Diagram for Attendance Management in Figure 2.

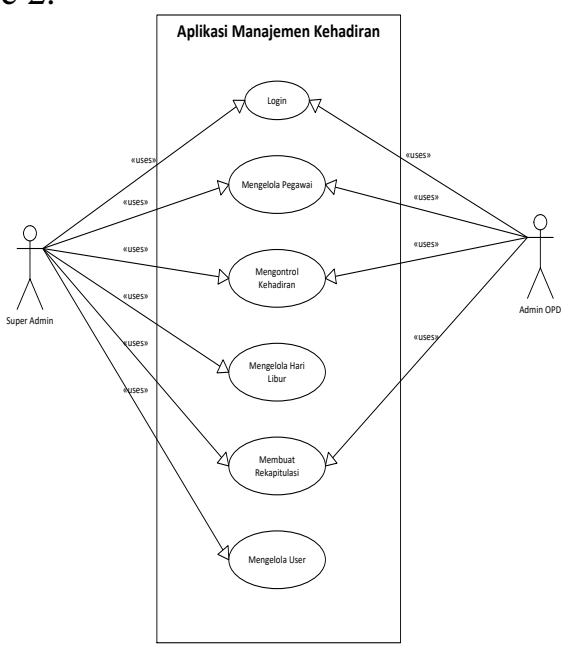

Figure 2. Use Case Diagram of the attendance management system 
In this attendance management application, there are two actors, namely Super Admin and Admin OPD.

1. All actors need to login to enter the system.

2. OPD admin can do the following process:

a. Managing Employees.

b. Review and control employee attendance.

c. Make a recapitulation of monthly attendance.

3. Super Admin can do all the existing processes:
a. Managing Employees.
b. Review and control employee attendance.
c. Make a recapitulation of monthly attendance.
d. Manage your holidays.
e. Manage users.
f. Manage attendance devices.

\section{RESULTS}

Implementation of the Attendance Management application that has been built in accordance with the description described in the previous explanation.

\section{Login View}

When it is first run, the system will display a login page and the user can enter the username and password that has been given. The following is the Login Display in Figure 3.

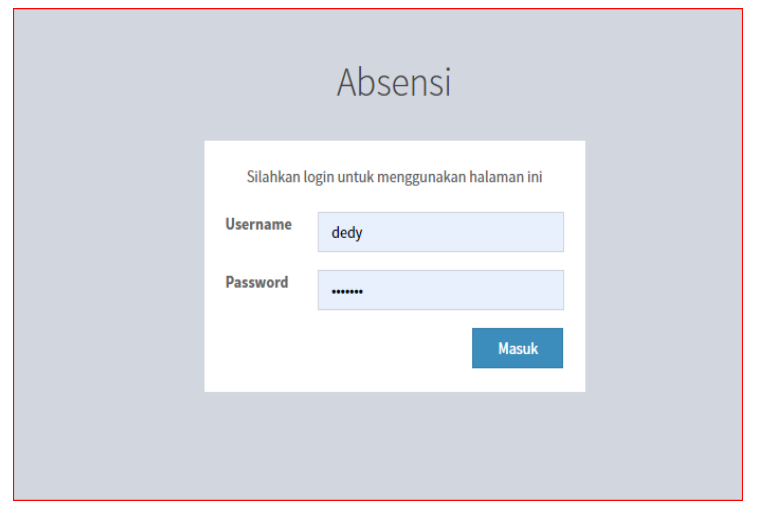

Figure 3. Login View

\section{Dashboard view}

After successfully logging in, the user will then be redirected to the Dashboard page, which is in the form of the initial or home screen. This page displays information in the form of:

1. Name of Service or OPD.

2. Summary of daily attendance in the form of: number of employees, number of employees on time, late and how many people were absent on that day.

3. Attendance percentage graph display

The following is the Dashboard View in Figure 4.

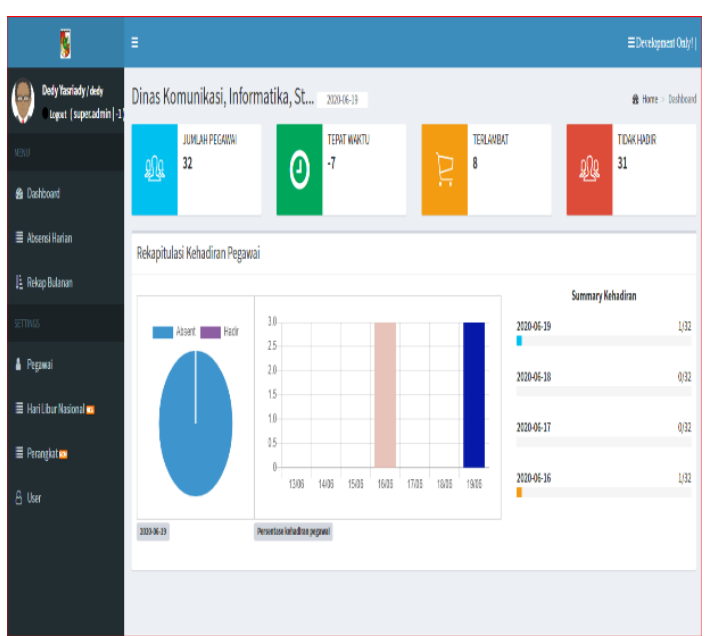

Figure 4. Dashboard View

\section{Daily Attendance}

The Daily Attendance page is used by the Admin to review and control employee attendance. On this page the Admin can change the employee attendance status. If the attendance photo shown is different from the reference photo of the employee concerned, the admin can change the Entry / Return status to Alpa. The following is the Daily Attendance View in Figure 5 .

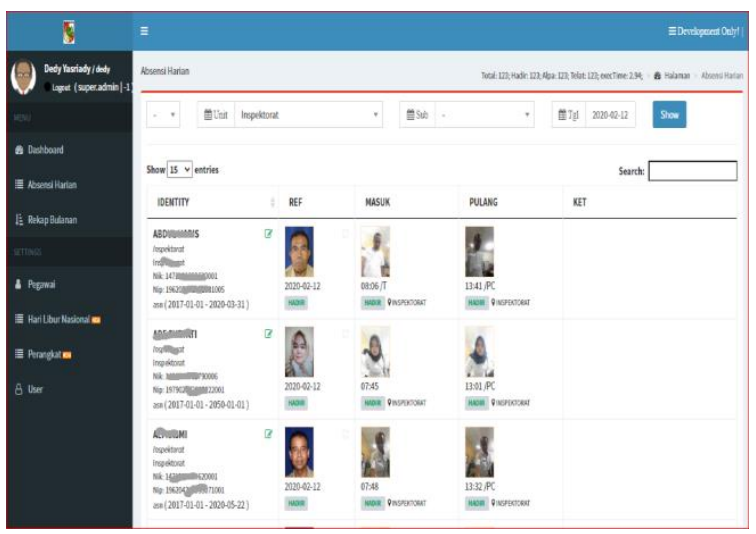

Figure 5. Daily Attandance View

\section{Monthly Recapitulation}

The results of the calculation of the total days, minutes late and the percentage of performance allowance deductions. The following is the Monthly Recapitulation View in Figure 6. 


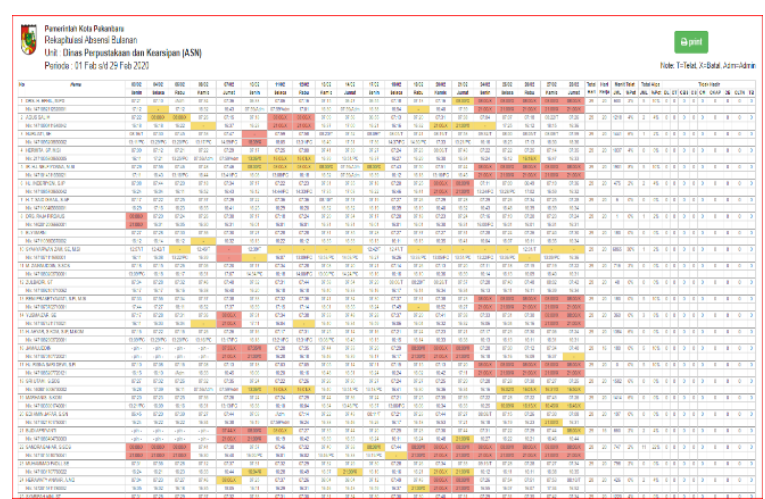

Figure 6. Monthly Recapitulation View

\section{DISCUSSION}

After the application is made and used in the Pekanbaru City Government service environment, the author conducts a questionnaire / survey regarding the performance of this application to get user responses. The survey was aimed at direct users of this application, which consisted of the Head of General Affairs and the OPD Admin. The total number of respondents involved in conducting the survey was 16 people. The questionnaire consists of 11 questions aimed at obtaining input on application performance The following is the Application performance questionnaire / survey in Table 1 .

Table 1. Application performance questionnaire / survey

\begin{tabular}{|c|c|c|c|c|c|}
\hline No & Question & $\mathbf{S}$ & $\mathbf{S}$ & TS & TS \\
\hline \multicolumn{6}{|c|}{ User Interface } \\
\hline 1 & $\begin{array}{l}\text { User interface / } \\
\text { appearance is easy } \\
\text { to use. }\end{array}$ & 16 & $100 \%$ & 0 & $0 \%$ \\
\hline \multicolumn{6}{|c|}{ Process } \\
\hline 2 & $\begin{array}{l}\text { Compared to } \\
\text { manual attendance } \\
\text { (daily initials), } \\
\text { smartmadani } \\
\text { attendance is more } \\
\text { efficient, more } \\
\text { efficient and easier } \\
\text { because it does not } \\
\text { print paper. }\end{array}$ & 16 & $100 \%$ & 0 & $0 \%$ \\
\hline 3 & $\begin{array}{l}\text { The Head of Sub- } \\
\text { Division of General } \\
\text { Affairs, Head of } \\
\text { Service and } \\
\text { Leadership can get } \\
\text { attendance } \\
\text { information as soon } \\
\text { as possible. }\end{array}$ & 16 & $100 \%$ & 0 & $0 \%$ \\
\hline 4 & $\begin{array}{l}\text { Benefits } \\
\text { calculations can be } \\
\text { made automatically } \\
\text { and more } \\
\text { accurately. }\end{array}$ & 14 & $88 \%$ & 2 & $13 \%$ \\
\hline 5 & $\begin{array}{l}\text { Attendance } \\
\text { information, } \\
\text { missing or late is } \\
\text { stored online and } \\
\text { easily accessible. }\end{array}$ & 16 & $100 \%$ & 0 & $0 \%$ \\
\hline 6 & $\begin{array}{l}\text { Compared to the old } \\
\text { method, the new } \\
\text { attendance } \\
\text { management makes } \\
\text { it easier for general } \\
\text { staff to recap } \\
\text { attendance reports. }\end{array}$ & 16 & $100 \%$ & 0 & $0 \%$ \\
\hline 7 & $\begin{array}{l}\text { Recapitulation of } \\
\text { attendance and } \\
\text { calculation of } \\
\text { performance } \\
\text { allowances can be }\end{array}$ & 16 & $100 \%$ & 0 & $0 \%$ \\
\hline
\end{tabular}

Printing of Monthly Reports / Recapitulations. The following is the Monthly Report View in Figure 8.

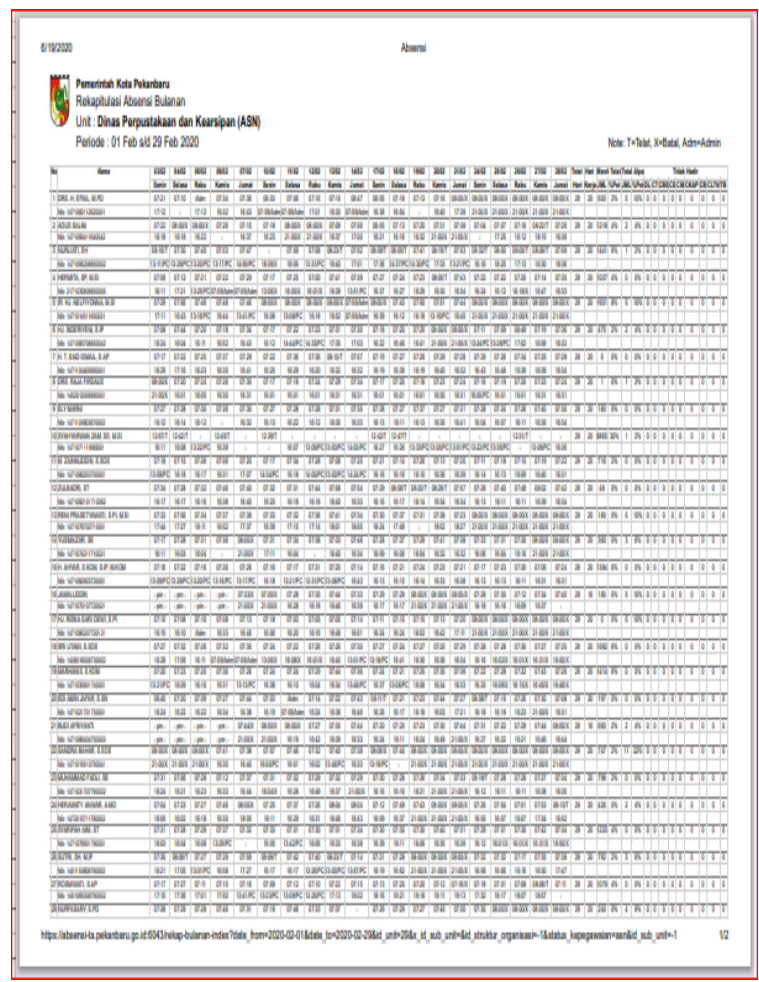

Figure 8. Monthly Report

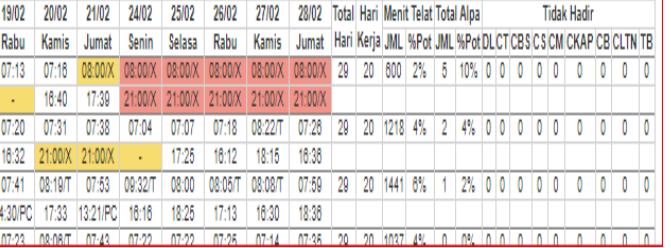

Figure 7. Calculate of total days View 


\begin{tabular}{|c|l|l|l|l|l|}
\hline & $\begin{array}{l}\text { prepared } \\
\text { immediately. }\end{array}$ & & & \\
\hline 8 & $\begin{array}{l}\text { The attendance } \\
\text { device is always } \\
\text { available when the } \\
\text { hours come and go } \\
\text { home. }\end{array}$ & 16 & $100 \%$ & 0 & $0 \%$ \\
\hline Output & $\begin{array}{l}\text { This smartmadani } \\
\text { attendance system } \\
\text { can reduce the } \\
\text { attendance behavior. }\end{array}$ & 16 & $100 \%$ & 0 & $0 \%$ \\
\hline 10 & $\begin{array}{l}\text { This new attendance } \\
\text { system motivates } \\
\text { employees to attend } \\
\text { on time because it is } \\
\text { related to Tukin. }\end{array}$ & 16 & $100 \%$ & 0 & $0 \%$ \\
\hline & $\begin{array}{l}\text { The employee } \\
\text { attendance rate has } \\
\text { increased since the } \\
\text { smartmadani } \\
\text { attendance was } \\
\text { implemented. }\end{array}$ & 16 & $100 \%$ & 0 & $0 \%$ \\
\hline
\end{tabular}

From the results of the survey conducted, it can be obtained the level of user satisfaction with the features provided by this application:

1. Ease of user interface : $100 \%$ agree

2. The process carried out by the application : $98 \%$ agree

3. The resulting output: $100 \%$ valid.

The following is the Application performance graph in Figure 9.

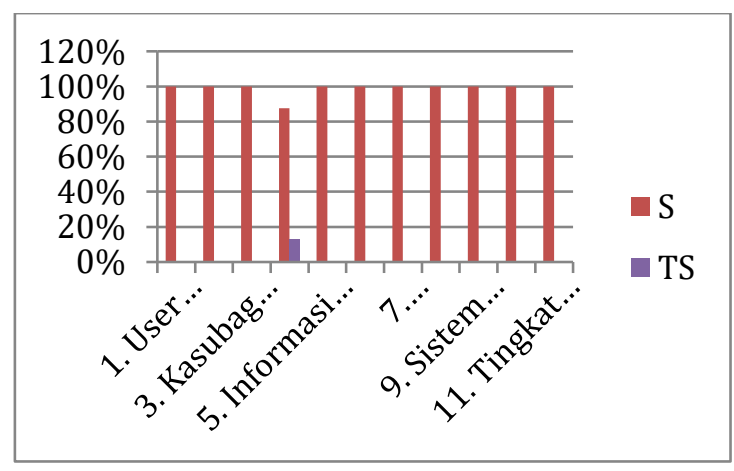

Figure 9. Application performance graph

From the data obtained from the Pekanbaru City Civil Service Agency and the Ministry of Communication and Information, it can be summarized in the following table 2 form:
Table 2. Comparison of Employee Attendance Data

\begin{tabular}{|c|c|c|c|c|}
\hline \multirow{2}{*}{$\begin{array}{l}\text { Service / } \\
\text { Agency }\end{array}$} & \multicolumn{2}{|c|}{ Old Attendance } & \multicolumn{2}{|c|}{ New Attendance } \\
\hline & Present & $\begin{array}{l}\text { Not } \\
\text { Present }\end{array}$ & Present & $\begin{array}{l}\text { Not } \\
\text { Present }\end{array}$ \\
\hline $\begin{array}{l}\text { Office of } \\
\text { Cooperatives, } \\
\text { Small and } \\
\text { Medium } \\
\text { Enterprises } \\
\end{array}$ & $91.7 \%$ & $8.3 \%$ & $99.4 \%$ & $0.6 \%$ \\
\hline $\begin{array}{l}\text { Fire and Rescue } \\
\text { Service }\end{array}$ & $91.7 \%$ & $8.3 \%$ & $99.1 \%$ & $0.9 \%$ \\
\hline $\begin{array}{l}\text { Human } \\
\text { Resources and } \\
\text { Human } \\
\text { Resources } \\
\text { Development } \\
\text { Agency } \\
\end{array}$ & $91.7 \%$ & $8.3 \%$ & $100.0 \%$ & $0.0 \%$ \\
\hline Inspectorate & $91.7 \%$ & $8.3 \%$ & $98.1 \%$ & $1.9 \%$ \\
\hline $\begin{array}{l}\text { Public Housing } \\
\text { and Settlement } \\
\text { Areas Service }\end{array}$ & $91.7 \%$ & $8.3 \%$ & $96.3 \%$ & $3.7 \%$ \\
\hline $\begin{array}{l}\text { Research and } \\
\text { Development } \\
\text { Agency }\end{array}$ & $91.7 \%$ & $8.3 \%$ & $97.6 \%$ & $2.4 \%$ \\
\hline $\begin{array}{l}\text { Regional } \\
\text { Planning and } \\
\text { Development } \\
\text { Agency }\end{array}$ & $91.7 \%$ & $8.3 \%$ & $99.3 \%$ & $0.7 \%$ \\
\hline $\begin{array}{l}\text { Trade and } \\
\text { Industry Service }\end{array}$ & $91.7 \%$ & $8.3 \%$ & $98.3 \%$ & $1.7 \%$ \\
\hline & $91.7 \%$ & $8.3 \%$ & $98.5 \%$ & $1.5 \%$ \\
\hline
\end{tabular}

The implementation of attendance devices in each OPD is carried out in stages starting in early 2020. In terms of procurement of attendance devices, not all DPOs have received attendance devices used in their respective offices. The attendance data in the table above is data taken in February 2020 for 1 full month.

\section{CONCLUSION}

From the results of the development of the Attendance Management application, several conclusions can be drawn which are also based on a questionnaire / survey on the level of user satisfaction with the features provided in accordance with the problem formulation that has been set at the beginning:

1. The application provides online information about employee attendance. Regional Leaders, Heads of Services / Agencies can monitor the condition of employee attendance in the Pekanbaru City Government online every day. 
2. Employee attendance reports for each Dinas / OPD are generated automatically. The Personnel and Human Resources Development Agency can use it as a monthly attendance summary report.

3. From the data obtained, the employee attendance rate has increased to $98.5 \%$ since the use of an online attendance management system was implemented, an increase of $6.8 \%$ compared to using a conventional system as shown in Table 5-2.

4. From the survey results, $100 \%$ of respondents agree that this new attendance system motivates employees to attend on time.

5. Employees are no longer able to take attendance actions because the daily attendance status is accompanied by a photo when they do attendance. The survey results show that $100 \%$ of respondents agree with this feature.

6. Calculation of employee performance allowance (Tukin) percentage is done easily, automatically and as soon as possible. The user survey shows that all respondents $100 \%$ agree with the convenience provided by the application.

7. Tukin calculations can be done accurately by minimizing the human error factor (human error) that often occurs in manual calculations, this is indicated by the response of survey participants that $88 \%$ agree with the features offered.

\section{REFERENCES}

Anhar. (2010). Panduan Menguasai PHP \& MySQL Secara Otodidak. Jakarta: Mediakita.

A. S., Rosa dan Shalahuddin, M. (2013). Rekayasa Perangkat Lunak Terstruktur Dan Berorientasi Objek. Informatika. Bandung.

Abd. Rachman Dayat \& Liza Angriani. (2017). Pemanfaatan Model-View-Controller (MVC) dalam Rancang Bangun Sistem Informasi. Rakornas Aptikom 2017.

Budi, Raharjo. (2016). Modul Pemrograman Web. Bandung : Penerbit Modula.

Harris, Andrew B. (2003). PHP / MySQL Programming for the Absolute Beginner, USA:

Hasibuan, Malayu.S.P . (2008). Manajemen Sumber Daya Manusia. Jakarta : PT. Bumi Aksara.

Jogiyanto. (2009).Sistem Teknologi Informasi. Yogyakarta : Andi Offset
Latif , Cahyono. (2017). Pengembangan Sistem Informasi Absensi Siswa Berbasis Web Di SMK YPKK 1 Sleman Yogyakar. Universitas Negeri Yogyakarta.

Made Praditha Gutama, A. A. Kompiang Oka Sudana, A.A. K. Agung Cahyawan W, (2014). Rancang Bangun Sistem Manajemen Absensi Kegiatan Banjar Berbasis Web. Jurusan Teknologi Informasi, Fakultas Teknik, Universitas Udayana Bukit Jimbaran, Bali, Indonesia. ISSN: 2252-3006.

Muhamad, Danuri. (2009). Object Oriented Programming Pemogramman Aplikasi Berbasis Window.

Naista, David. (2016). Bikin Framework PHP Sendiri dengan Teknik OOP dan MVC.

Nurikawati, Rika. (2016). Rancang Bangun Aplikasi Absensi Pegawai Berbasis Web.Proceeding STIMA.

Setiawan, Parta . (2015). Pengertian Absensi dan Jenisjenis Absensi. Diambil dari: http://www.gurupendidikan.com/pengertian-danjenis-jenis-absensi (16 Februari 2021)

Susanto, Azhar. (2004). Sistem Informasi Manajemen Konsep dan Pengembangan, Bandung, Lingga Jati.

Suci, Gita. (2018). Rancang Bangun Aplikasi Sistem Absensi Karyawan Pada PT.XYZ. Jurnal Komunikasi, Media dan Informatika Vol 7 No 2. (16 Februari 2021).

S. Pressman, Roger, Ph.D.(2010). Rekayasa Perangkat Lunak Pendekatan Praktisi Edisi 7 .Andi. Yogyakarta.

Taufiq, Rohmat. (2013). Sistem Informasi Manajemen. Yogyakarta: Graha Ilmu. 